\title{
Should REIT Investors be Concerned about Changing Economic Conditions?
}

\author{
Martin Červeny"
}

\begin{abstract}
:
Current economic development in global markets promises gradually rising interest rates, which seems to concern many investors of the Real Estate Investment Trusts (REITs). The aim of this article is, based on the data from 1972 through 2017, to describe the sensitivity of REITs' total returns to those of the stock market and to the dynamics of interest rates, and to compare the findings with previous research published during the 1990s in order to identify any shifts in the market behaviour. Our OLS regression models will study the effects of the stock market performance and changes in interest rates on both the equity and mortgage REITs. As we will demonstrate, REITs remain sensitive to the stock market performance, but changes of interest rates have little temporary effect on their performance. Contrarily to popular beliefs, there is little evidence that long-term oriented and diversified REIT investors should be overly concerned about rising interest rates.
\end{abstract}

Key words: REIT; Real Estate Investment Trust; Interest Rate.

JEL classification: G12.

\section{Introduction}

Ever since the concept of equity trading was introduced to the public, investors have been striving to discover the best ways to beat the market. Real Estate Investment Trusts (REITs), investment vehicles introduced in the 1960s and primarily focused on income-oriented investors, have consistently outperformed the rather conservative bond investment funds in total return measures. Due to their generous payout ratios exceeding $90 \%$ by law, widely perceived safety thanks to the real estate collateral, and relatively low cost of capital, REITs have become an effective way in which stockholders could participate in real estate investments.

Some authors, however, have pointed out the potential risks of such investments that the investors should always be aware of. Particularly, they argue that REITs in their business models resemble sophisticated financial institutions rather than just simplistic real estate owners or operators. The important caveat is that since REITs raise capital through stocks issued at significant premiums to book values, and due

Martin Červený; University of Economics, Prague, Faculty of Finance and Accounting, Department of Corporate Finance, W. Churchill Sq. 4, 13067 Prague, Czech Republic, <martin.cerveny@vse.cz>.

The article is processed as an output of an institutional support registered by the Czech Grant Agency under the registration number VSE IP100040. 
to their high dependence on financial leverage, these might be strongly vulnerable to volatile macroeconomic conditions and market turbulences.

For instance, Park, Mullineaux and Chew (1990) pointed out that REITs are mostly correlated with the general stock market and they offer virtually no benefits in one's hedging strategy. Moreover, Cummins and Zochling (2011) suggest that because of their high payout ratios, REITs experience limited reinvestment opportunities, which, in turn, adversely affects their total returns over longer investment horizons.

On the other hand, Clayton and MacKinnon (2001) claim that REITs experience lower volatilities during downturns or serious market crashes, which gives them a perceived notion of safe havens in the eyes of risk-averse investors. This idea was also discussed by Allen et. al. (2000) who argue that REITs heavily concentrated in a specific type of property may be able to focus and therefore achieve a lower level of risk. Still, their empirical research confirmed a notable dependence of REITs' performance on the broad stock market condition. Similar results presented for example Liang et. al. (1995), Seiler et. al. (2001), or Case et. al. (2012). Some of the results showed that the market risk has declined significantly over time for REITs as the industry beta was lower in late 1980s compared to the 1970s (Liang et. al., 1995).

At the time of writing of this paper (early 2018), i.e. almost ten years after the last crisis that shocked the entire financial world and caused asset prices to shrink to the levels unseen in decades, central banks around the world have switched to "hawkish" modes, triggering several interest rates' hikes within just six months. The financial periodicals are full of headlines warning about the presumed sensitivity of REITs to interest rate dynamics. Numerous authors in the past have examined this relationship in their papers. Namely, Chen and Tzang (1988) were one of the pioneers who confirmed the negative correlation between interest rates and performance of the REIT sector. However, the indicated sensitivity was lower for equity REITs versus their mortgage-oriented peers. He et. al. (2003) have used various proxies of interest rates to better describe the relationship. Their calculations showed that the relatively strongest relationship was to be found with high grade government or corporate bonds. Mueller and Pauley (1995) argue that REITs' returns depend on directional movements of interest rates rather than on absolute values of yields.

These days, there seems to be little doubt about REITs being sensitive to interest rates. Still, the seriousness and permanency of these effects remain unclear. Investors, aware of the expected interest rates' rises, seem to have incorporated their concerns into the prices of REITs, because the sector has underperformed the market significantly over the past year. While the S\&P 500 was up $21.8 \%$ during the year 2017, the REIT sector managed to deliver the total return of just $9.2 \%$ 
over the same period. We are, however, quite at the beginning of a new era, symbolised by changing economic conditions and, perhaps, by a return to the normal, pre-crisis interest rates.

Many studies on REITs' sensitivities are somewhat dated, published during early 1990 , and only a handful of papers were based on data prior to 2009. In addition, these studies examine the phenomenon of market cycles and interest rates typically separately, while I suggest these could be examined in a bundle. Thus, the aim of this article is to examine and describe the simultaneous relationship between the REITs' total returns, stock market performance, and the incremental changes of various interest rates. The findings, based on the most recent data available, will be compared with the data on which the previous research was based in order to discover any possible shifts in the market behaviour. These conclusions will be used to better understand the challenges the REIT sector might experience during the times of changing economic conditions, namely stock market corrections and interest rates' hikes, from the perspective of a long-term oriented, diversified investor.

\section{Data and Methodology}

To fulfil the goal, multiple linear regression models will be utilised. Based on the correlation analysis, the best proxies for the general stock market and interest rates will be selected for the models. For our purpose, the REIT sector will be represented by the FTSE Nareit Index, an instrument that traces the performance of the industry since $1972 .{ }^{1}$ Similarly to Chen and Tzang (1988), we will consider the whole index as well as its separate equity (e-REITs) and mortgage (m-REITs) components. Performance of the general stock market will be embodied in the S\&P 500 index. Unlike some of the previous researches, I will focus strictly on total annual returns and not just prices, as the dividend income is typically the crucial component for most REIT portfolios.

Regarding the interest rate factor, similarly to He et. al. (2003) several representatives were considered, including the short-term treasury bills (T-bills), long-term treasury bonds (T-bonds), and the basic FED rate. ${ }^{2}$ Preliminary testing included numerous corporate bond related rates. Most of them, however, showed very little significance and were thus omitted from further analyses. Rather than nominal yields, dynamics of the interest rates will be important to our study. At least in theory, over the long run REITs should be able to renegotiate the terms of their contracts in order to mitigate the adverse effects of virtually any level of interest rates. Hence, investors seem to be more concerned about the direction and

1 For an overview of the FTSE Nareit constituents in the main components, see Appendix 1.

2 Data about the interest rate proxies were provided through the courtesy of the St. Louis Fed Economic Research. For more information, please see FED (2018). 
intensity of sudden interest rates' hikes. These assumptions were also confirmed by Mueller and Pauley (1995).

To sum up, the following variables will appear in my study:

$R E I T=$ total annual returns of the FTSE Nareit Index,

EREIT $=$ total annual returns of the FTSE Equity Nareit Index,

$M R E I T=$ total annual returns of the FTSE Mortgage Nareit Index,

$R E I T+1=$ total annual returns of the FTSE Nareit Index with one-year lag included, i.e. forward annual returns,

EREIT $+1=$ total annual returns of the FTSE Equity Nareit Index with oneyear lag included, i.e. forward annual returns,

$M R E I T+1=$ total annual returns of the FTSE Mortgage Nareit Index with one-year lag included, i.e. forward annual returns,

$S \& P=$ total annual returns of the $\mathrm{S} \& \mathrm{P} 500$ index,

$\triangle T B O N D=$ percentage annual changes in yields of T-bonds, rates effective at the beginning of each year,

$\triangle T B I L L=$ percentage annual changes in yields of T-bills, rates effective at the beginning of each year,

$\triangle F E D=$ percentage annual changes in the basic FED rate.

To evaluate the applicability of findings from the previous studies to present-day conditions, this study will compare basic statistic parameters separately first for the period 1972-1990 and then for the period 1972-2017 and discuss, whether the sensitivity has undergone any changes worth attention.

Subsequently, OLS regression models will be introduced for both the abovementioned periods. Based on the regression model results, I will be able to better illustrate the possible impacts of the changing economic environment in the foreseeable future, namely the gradually rising interest rates or, potentially, the temporary interruption of the growing economic cycle or a more serious stock market correction.

The threshold date of 1990 was chosen due to the fact that many of the pioneering studies on REITs were sensitive to interest rates or the stocks were based on data that ended between 1987 and 1990 (e.g. Chen and Tzang, 1988; Park, Mullineaux, and Chew, 1990), while many researchers have simply repeated these conclusions ever since. The preliminary analysis will also focus on the post-crisis period, i.e. since 2009, with the intention to describe the specific characteristics of the respective period that are expected to change in the foreseeable future. 


\section{Sensitivity of REITs to Stock Performance and Interest Rate Dynamics}

\subsection{Changes in sensitivity of REITs to market conditions}

Figure 1 shows that in terms of the total returns, during the period 1972-2017 REITs underperformed the market for most of the time. Ignoring any transaction costs, USD 100 invested in 1972 would be worth USD 9,973 if one invested in the market index, but only USD 7,146 had s/he invested in REITs. Still, it appears that the patterns for growth and recessions were quite similar, except for early 2000s, because the real estate sector remained unaffected by the "dot-com" frenzy.

Interestingly, further inspection of the chart shows that REITs in total underperformed the stock index mainly due to the mortgage-oriented component. The cumulative return in 2017 would total USD 16,772 in the case of the equity portion, while the mortgage peers would return just USD 1,203! The m-REITs have always been perceived as riskier investment vehicles as they suffered large losses during the late 1980s and late 1990s, as well as during the most recent recession. The underdog, however, did quite well in the past two years (i.e. since 2016), as it averaged a total return of $21.32 \%$ annually.

\section{Fig. 1 REIT vs. S\&P 500 cumulative total returns (1972-2017)}

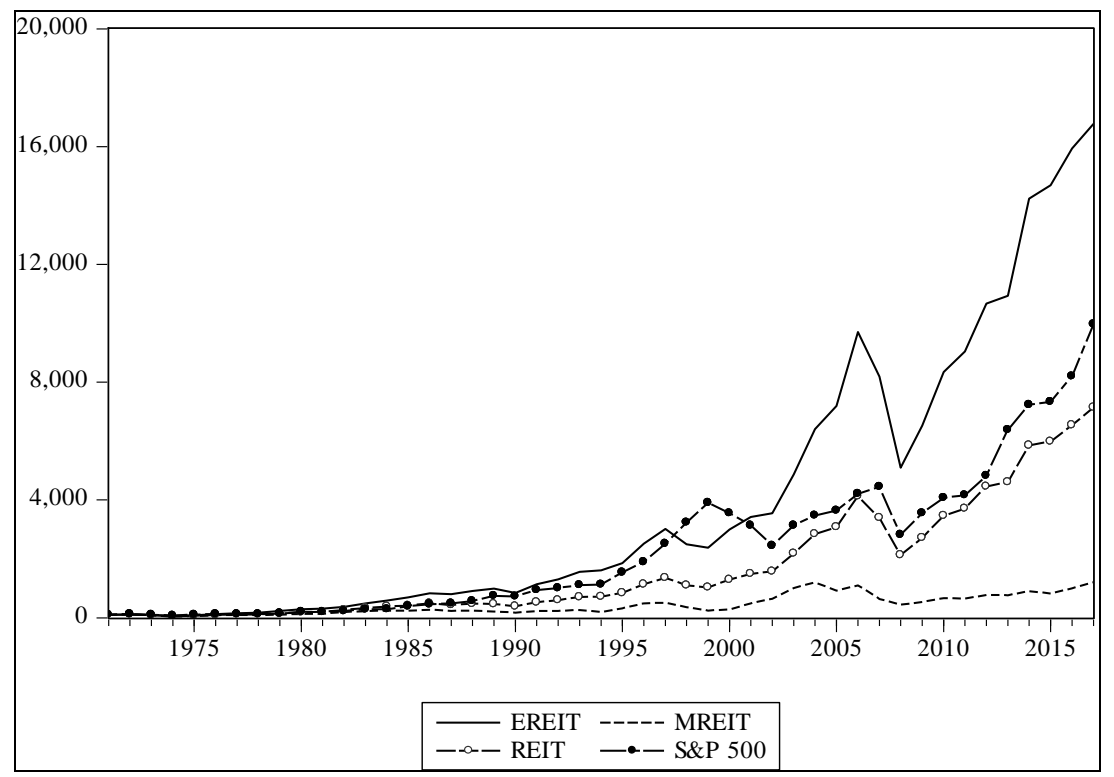

Source: Nareit (2018a), Yahoo Finance (2018) + authorial computation.

Figure 2 depicts the total returns of REITs in contrast to various interest rates. One can observe a gradual decrease in all interest rates since 1982 with several 
temporary spikes, when in 2010 the short-term rates finally approached near-zero values.

Fig. 2 REIT total returns vs. various interest rate proxies (1972-2017)

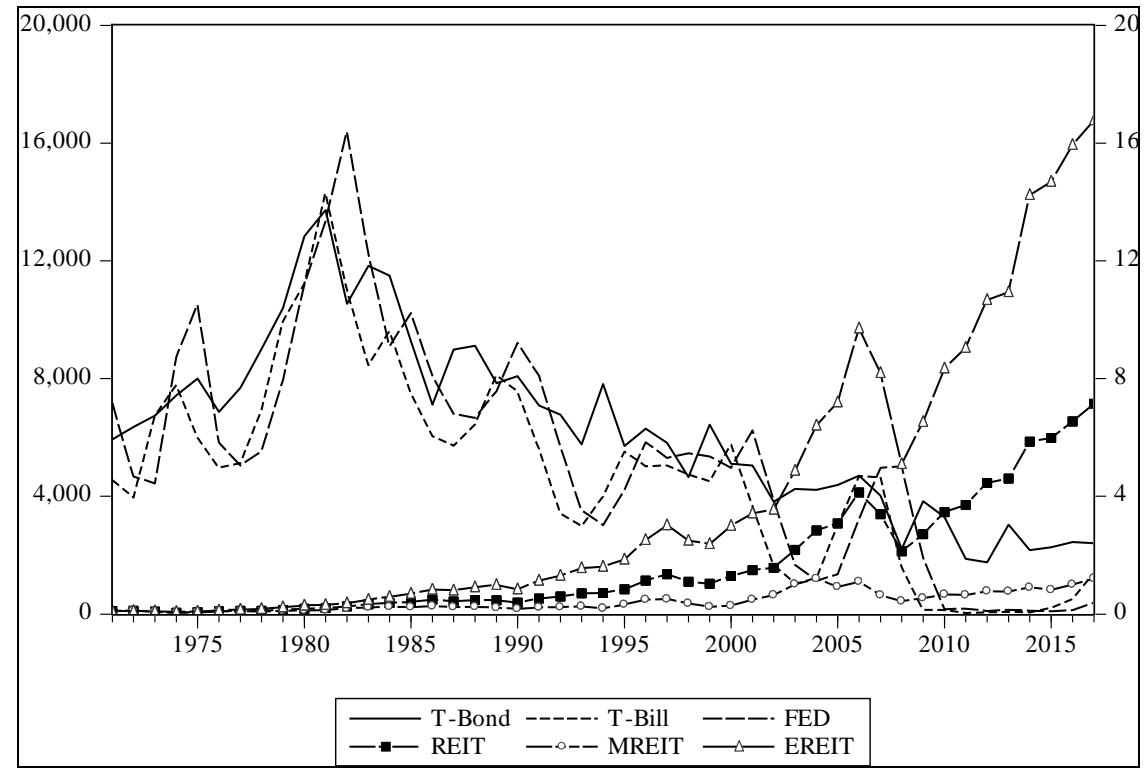

Source: Nareit (2018a), FED (2018) + authorial computation.

Note: REIT is depicted on the left axis, interest rates on the right axis of the chart.

More importantly, Table 1 provides basic statistical summary and correlations for the first period relevant to my research, i.e. from 1972 through 1990.

In line with some of the previous findings, there is a significant positive correlation of 0.72 between the REIT industry and the broad stock market. The equity and mortgage components are strongly correlated with each other during the entire period and both show significant correlations with the stock market as well, while the m-REITs have a slightly smaller coefficient of 0.63 .

On the other hand, one could observe somewhat less substantial negative correlations with all the interest rate proxies. Statistically significant correlation of -0.55 was measured between T-bills and the m-REITs. T-bills were also negatively correlated with the S\&P 500 index. Overall, the results presented in Table 1 show stronger negative correlations between REITs and the short-term interest rate proxies compared to the long-term T-bonds. 
Tab. 1 Summary statistics for the period 1972-1990

\begin{tabular}{|c|c|c|c|c|c|c|c|c|c|}
\hline \multirow{2}{*}{ Variable } & \multirow{2}{*}{ Mean } & \multirow{2}{*}{ SD } & \multicolumn{7}{|c|}{ Correlations } \\
\hline & & & [1] & [2] & [3] & [4] & [5] & [6] & [7] \\
\hline [1] REIT & 10.00 & 22.90 & 1.00 & & & & & & \\
\hline [2] EREIT & 13.25 & 17.76 & $* 0.94$ & 1.00 & & & & & \\
\hline [3] MREIT & 6.08 & 26.00 & $* 0.96$ & $* 0.84$ & 1.00 & & & & \\
\hline [4] S\&P & 12.31 & 17.20 & $* 0.72$ & $* 0.68$ & $* 0.63$ & 1.00 & & & \\
\hline$[5] \triangle \mathrm{TBOND}$ & 2.75 & 15.10 & -0.22 & -0.23 & -0.30 & -0.30 & 1.00 & & \\
\hline [6] $\Delta$ TBILL & 5.65 & 26.51 & -0.45 & -0.35 & $*_{-0.55}$ & $*_{-} 0.47$ & 0.37 & 1.00 & \\
\hline [7] $\triangle \mathrm{FED}$ & 5.97 & 33.23 & -0.40 & -0.40 & -0.38 & -0.26 & 0.21 & 0.29 & 1.00 \\
\hline
\end{tabular}

Source: Nareit (2018a), Yahoo Finance (2018), FED (2018) + authorial computation.

Note: Pearson correlation coefficients are presented. Asterisks $(*)$ indicate significance on the $95 \%$ confidence level.

Table 2 displays the statistics for the entire period 1972-2017.

Tab. 2 Summary statistics for the period 1972-2017

\begin{tabular}{|c|c|c|c|c|c|c|c|c|c|}
\hline \multirow{2}{*}{ Variable } & \multirow{2}{*}{ Mean } & \multirow{2}{*}{ SD } & \multicolumn{7}{|c|}{ Correlations } \\
\hline & & & {$[1]$} & [2] & [3] & [4] & [5] & [6] & [7] \\
\hline [1] REIT & 11.77 & 20.17 & 1.00 & & & & & & \\
\hline [2] EREIT & 13.30 & 17.81 & $* 0.96$ & 1.00 & & & & & \\
\hline [3] MREIT & 9.40 & 28.50 & $* 0.81$ & $* 0.73$ & 1.00 & & & & \\
\hline [4] S\&P & 11.95 & 17.11 & $* 0.56$ & $* 0.53$ & $* 0.36$ & 1.00 & & & \\
\hline$[5] \triangle \mathrm{TBOND}$ & 0.68 & 23.93 & 0.03 & 0.05 & -0.10 & 0.21 & 1.00 & & \\
\hline [6] $\triangle$ TBILL & 14.62 & 69.52 & -0.11 & -0.11 & -0.18 & -0.02 & 0.13 & 1.00 & \\
\hline [7] $\triangle \mathrm{FED}$ & 5.50 & 50.03 & -0.21 & -0.23 & -0.11 & 0.00 & 0.04 & $* 0.36$ & 1.00 \\
\hline
\end{tabular}

Source: Nareit (2018a), Yahoo Finance (2018), FED (2018) + authorial computation.

Note: Pearson correlation coefficients are presented. Asterisks $(*)$ indicate significance on the $95 \%$ confidence level.

It is apparent that the REITs' performance was relatively less affected by the external economic conditions. Although correlation with the stock market remains statistically significant, it is notably lower with a coefficient of just 0.56 . The mortgage component demonstrates correlation of just 0.36 . Thus, REITs seem as a less volatile investment compared to stocks with an estimated beta lower than 1 . 
The sensitivity to shifts in interest rates has quite deteriorated over time. In both cases, the short-term proxies of interest rates showed relatively higher negative correlation during the entire period, with coefficients of -0.11 and -0.21 for T-Bills and the FED rate, respectively - still significantly lower from the the 1990s' values. Same conclusions can be drawn for each of the components. The e-REITs seem to be more negatively correlated with the FED rate, while the m-REITs show a mildly stronger negative correlation with T-bills, both lacking any statistical significance.

Based on the findings from both periods, the FED rate was selected as a proxy for the interest rate dynamics component in the models, because a) being a short-term proxy, it demonstrated a relatively higher significance compared to T-bonds, and b) it demonstrated relatively weaker negative correlation with the stock market, which will enhance usability of the multivariable models.

\subsection{Permanency of the effects (analysing forward returns)}

Our next step in the REIT sensitivity analysis leads us to the obvious question, whether changes in interest rates influence future returns of REITs. Negative correlation would imply that a present-day hike in interest rates will have an adverse effect on the future total performance of the REIT sector and vice versa.

Table 3 shows a summary for the correlation analysis when we applied the forward total returns of REITs on the first period. Again, preliminary testing included longer time horizons of future returns, but due to very small significance, these results were omitted in this paper.

\section{Tab. 3 Summary statistics using forward REIT returns (1972-1990)}

\begin{tabular}{|c|c|c|c|c|c|c|c|c|c|}
\hline \multirow{2}{*}{ Variable } & \multirow{2}{*}{ Mean } & \multirow{2}{*}{ SD } & \multicolumn{7}{|c|}{ Correlations } \\
\hline & & & [1] & [2] & [3] & [4] & [5] & [6] & [7] \\
\hline [1] REIT+1 & 11.30 & 23.65 & 1.00 & & & & & & \\
\hline [2] EREIT+1 & 14.71 & 18.42 & $* 0.94$ & 1.00 & & & & & \\
\hline [3] MREIT+1 & 7.12 & 26.64 & $* 0.96$ & $* 0.86$ & 1.00 & & & & \\
\hline [4] S\&P & 12.31 & 17.20 & 0.04 & 0.08 & 0.00 & 1.00 & & & \\
\hline$[5] \triangle \mathrm{TBOND}$ & 2.75 & 15.09 & 0.14 & 0.11 & 0.11 & -0.30 & 1.00 & & \\
\hline$[6] \Delta$ TBILL & 5.65 & 26.51 & -0.29 & -0.33 & -0.26 & $*_{-0.47}$ & 0.37 & 1.00 & \\
\hline [7] $\triangle \mathrm{FED}$ & 5.97 & 33.23 & $* 0.49$ & 0.28 & $* 0.53$ & -0.26 & 0.21 & 0.29 & 1.00 \\
\hline
\end{tabular}

Source: Nareit (2018a), Yahoo Finance (2018), FED (2018) + authorial computation.

Note: Pearson correlation coefficients are presented. Asterisks (*) indicate significance on the $95 \%$ confidence level. 
Interestingly, one could conclude that the effects of the interest rates do even out within the following year or so, based on the significant positive correlation of 0.49 between the REIT+1 and the $\triangle F E D$. This effect is enhanced even more in the case of m-REITs, which show a significant positive correlation of 0.53 . On the contrary, non-significant negative correlation was evident with T-bills.

As we can see from Table 4, these effects did not hold during the whole period from 1972 through 2017. Virtually no correlation was detected with either of the interest rate proxies. Based on the data below, it seems that REITs' future returns are not affected by sudden changes in interest rates.

Tab. 4 Summary statistics using forward REIT returns (1972-2017)

\begin{tabular}{|c|c|c|c|c|c|c|c|c|c|}
\hline \multirow{2}{*}{ Variable } & \multirow{2}{*}{ Mean } & \multirow{2}{*}{ SD } & \multicolumn{7}{|c|}{ Correlations } \\
\hline & & & [1] & [2] & {$[3]$} & [4] & [5] & [6] & [7] \\
\hline [1] REIT+1 & 11.79 & 20.39 & 1.00 & & & & & & \\
\hline [2] EREIT+1 & 13.42 & 18.00 & $* 0.96$ & 1.00 & & & & & \\
\hline [3] MREIT+1 & 9.34 & 28.82 & $* 0.81$ & $* 0.73$ & 1.00 & & & & \\
\hline [4] S\&P & 11.95 & 17.11 & -0.05 & -0.02 & -0.24 & 1.00 & & & \\
\hline$[5] \Delta \mathrm{TBOND}$ & 0.68 & 23.93 & 0.16 & 0.18 & 0.08 & 0.21 & 1.00 & & \\
\hline$[6] \Delta \mathrm{TBILL}$ & 14.62 & 69.52 & -0.11 & -0.14 & 0.00 & -0.02 & 0.13 & 1.00 & \\
\hline [7] $\triangle \mathrm{FED}$ & 5.50 & 50.03 & 0.02 & -0.10 & 0.03 & 0.00 & 0.04 & $* 0.36$ & 1.00 \\
\hline
\end{tabular}

Source: Nareit (2018a), Yahoo Finance (2018), FED (2018) + authorial computation.

Note: Pearson correlation coefficients are presented. Asterisks $(*)$ indicate significance on the $95 \%$ confidence level.

\subsection{The post-crisis period}

During the post-crisis period, following the recession in 2007-8, one can observe some interesting patterns in the data. First, e-REITs and m-REITs appear to be less correlated with each other plus none of the REIT components showed any significant correlation with the stock market. Moreover, even though no statistical significance could be confirmed, the short-term interest rates indicate relatively high negative coefficients with both types of REITs.

It is fair to point out, however, that we can hardly derive any conclusions from this data. Not only is the post crisis period still too short to capture a complete economic cycle, but as we have indicated, this time was characterized by actions from the central banks, such as interest rates forced near to zero (any changes appear to be more robust when starting off from a small base), as well as direct purchases in the equity markets. Therefore, most equities enjoyed a continuous growth while the interest rates remained near their all-time lows. For these reasons 
I argue that along with the long-term orientation of my implications, we should primarily focus on the longer time frames available.

Tab. 5 Post crisis period (2009-2017)

\begin{tabular}{|c|c|c|c|c|c|c|c|c|c|}
\hline \multirow{2}{*}{ Variable } & \multirow{2}{*}{ Mean } & \multirow{2}{*}{ SD } & \multicolumn{7}{|c|}{ Correlations } \\
\hline & & & {$[1]$} & {$[2]$} & {$[3]$} & {$[4]$} & [5] & [6] & [7] \\
\hline [1] REIT & 14.85 & 10.68 & 1.00 & & & & & & \\
\hline [2] EREIT & 14.65 & 11.47 & $* 0.99$ & 1.00 & & & & & \\
\hline [3] MREIT & 12.71 & 13.14 & $* 0.75$ & 0.65 & 1.00 & & & & \\
\hline [4] S\&P & 15.47 & 10.13 & 0.20 & 0.12 & 0.36 & 1.00 & & & \\
\hline$[5] \triangle \mathrm{TBOND}$ & 7.23 & 40.63 & -0.07 & -0.10 & 0.02 & $* 0.76$ & 1.00 & & \\
\hline$[6] \Delta$ TBILL & 59.80 & $\begin{array}{r}133.0 \\
1\end{array}$ & -0.61 & -0.63 & -0.32 & -0.29 & -0.04 & 1.00 & \\
\hline [7] $\triangle \mathrm{FED}$ & 6.61 & 85.38 & -0.57 & -0.64 & -0.07 & 0.18 & -0.02 & 0.40 & 1.00 \\
\hline
\end{tabular}

Source: Nareit (2018a), Yahoo Finance (2018), FED (2018) + authorial computation.

Note: Pearson correlation coefficients are presented. Asterisks $(*)$ indicate significance on the $95 \%$ confidence level.

\subsection{Regression results}

The subsequent step in our analysis is to estimate the sensitivity of REITs to the two selected market performance indicators, i.e. market return and interest rates. The formal OLS model can be described by the following equation:

$$
\operatorname{REIT}_{t}=c_{0}+c_{1} R_{M, t}+c_{2} i_{t}+\mu_{t},
$$

where REIT represents the total annual returns for REITs; $R_{M}$ is the market return; $i$ stands for the interest rate; $c_{x}$ are the coefficients to be estimated; $\mu$ is the error term; and $t$ represents the respective years.

Our model outputs are summarised in Table 6. Two models were assembled for each of the REIT components. Models A, B, C are based on a sample from 1972 to 1990 , models D, E, F capture the entire period. Comparison of the two periods will allow us to better understand the premises that the previous research was based upon and discuss its applicability on the current market conditions. 
Tab. 6 OLS regression results

\begin{tabular}{|c|c|c|c|c|c|c|}
\hline Model & $\begin{array}{l}\text { Dependent } \\
\text { variable }\end{array}$ & Period & Intercept & S\&P & $\Delta$ FED & $\mathbf{R}^{2}$ \\
\hline A & REIT & $1972-1990$ & $\begin{array}{r}0.12 \\
(0.02)\end{array}$ & $\begin{array}{r}0.88 \\
(3.88)^{*}\end{array}$ & $\begin{array}{r}-0.16 \\
(-1.33)\end{array}$ & 0.57 \\
\hline B & EREIT & $1972-1990$ & $\begin{array}{r}6.16 \\
(1.57)\end{array}$ & $\begin{array}{r}0.63 \\
(3.42)^{*}\end{array}$ & $\begin{array}{r}-0.12 \\
(-1.31)\end{array}$ & 0.51 \\
\hline $\mathrm{C}$ & MREIT & $1972-1990$ & $\begin{array}{r}-3.35 \\
(-0.55)\end{array}$ & $\begin{array}{r}0.85 \\
(2.94)^{*}\end{array}$ & $\begin{array}{r}-0.19 \\
(-1.23)\end{array}$ & 0.45 \\
\hline D & REIT & $1972-2017$ & $\begin{array}{r}4.29 \\
(1.44)\end{array}$ & $\begin{array}{r}0.66 \\
(4.62)^{*}\end{array}$ & $\begin{array}{r}-0.08 \\
(-1.72)\end{array}$ & 0.36 \\
\hline $\mathrm{E}$ & EREIT & $1972-2017$ & $\begin{array}{r}7.11 \\
(2.64)\end{array}$ & $\begin{array}{r}0.55 \\
(4.29)^{*}\end{array}$ & $\begin{array}{r}-0.08 \\
(-1.83)\end{array}$ & 0.34 \\
\hline $\mathrm{F}$ & MREIT & $1972-2017$ & $\begin{array}{r}2.61 \\
(0.53)\end{array}$ & $\begin{array}{r}0.60 \\
(2.53)^{*}\end{array}$ & $\begin{array}{r}-0.06 \\
(-0.78)\end{array}$ & 0.14 \\
\hline
\end{tabular}

Source: Authorial computation.

Note: T-statistics of variables in parentheses. Asterisks (*) indicate significance on the 95\% confidence level. For additional model diagnostics, please see Appendix 2.

\section{Discussion}

The OLS estimates generally confirm our preliminary conclusions from the correlation analysis as well as the findings presented for instance by Park, Mullineaux, and Chew (1990). The stock market component shows statistical significance with coefficients of 0.88 and 0.66 for the entire REIT industry ${ }^{3}$ (models A and D, respectively), which was confirmed by the Wald tests for difference in both cases ${ }^{4}$. The decrease in coefficients might be translated as a decline of the REIT industry's beta. Apparently, this decrease is a continuation of the trend first identified by Liang et. al. (1995). Similar conclusions can be observed with both REIT components, while m-REITs have larger betas of 0.85 and 0.60 (models $\mathrm{C}$ and $\mathrm{F}$ ) compared to e-REITs with 0.63 and 0.55 , respectively (models B and E). Based on the statistical significance of this variable in all cases, it can be concluded that REITs generally do follow the patterns of the stock market, which might be caused by the sheer liquidity rather than by changes in the intrinsic value of the assets.

Based on the correlation analysis, I have established that the REITs' behaviour can be better explained by the movements of the short-term interest rate proxies, such as the T-bills or the FED rate. Interestingly, these patterns seem to be immediate as there was virtually no significance once the lags in REITs' performance were

\footnotetext{
3 Please note that these coefficients are a representation of the industry's risk, also known as "beta".

4 See Appendix 2.
} 
included. During the period 1972-1990, we even saw a positive correlation between the short-term FED rate and the forward REITs' returns, which suggested that the negative effects of interest rates' hikes were mitigated within the following year, at least to some extent. The obvious explanation of this result might be that the changes of interest rates only have a temporary effect on the REITs' performance.

The T-bills appeared to have more impact on the m-REITs during the 1972-1990 period but these were also negatively correlated with the stock market, which would lead to a stronger mutual correlation of independent variables. According to my analysis of the initial period, we could basically confirm the negative impact of rising interest rates, just like Chen and Tzang (1988) indicated. We could also confirm their statement that m-REITs are generally more sensitive to interest rate changes and more volatile. Even though m-REITs remained highly volatile during the subsequent years, the negative correlation with interest rates somewhat eroded, as these effects were not confirmed by the data covering the entire period. Thus, counter to previous research, a clear lack of significance in the case of interest rate dynamics can be observed within all models, while models D, E, F show even lower negative coefficients in terms of the FED rate dynamics.

The theory suggests several possible explanations for the presumed sensitivity. First, due to the high financial leverage, rising interest rates cause the cost of servicing debt to increase. Probably, this phenomenon in reality causes only provisional distress, because the management can renegotiate the contracts once the leases expire in order to mitigate any adverse effects on the operating margins. Similar logic can be applied to the mortgage REITs - even though in theory interest rates determine their margins, mREITs might be able to swiftly transfer the rising costs onto the mortgagees.

Another reason is that rising rates are making an impact on the U.S. savings rate, which causes the incremental demand for equities to decline. This, however, creates concern among investors that rising interest rates will wreak havoc on all types of securities, not just REITs. Therefore, we cannon conclude that REITs' risk is significantly higher than the risk of other publicly traded equities.

Quite interestingly, the overall ability of the selected independent variables to fit the data through the model deteriorates over time. The $\mathrm{R}^{2}$ coefficients decreased from 0.57 in Model A to 0.36 in Model D. Similar patterns were observable with both index components. This indicates that the markets behaved differently from the past during the latest period (1991-2017). Tests of the forecasting ability ${ }^{5}$ indicate a lower explanatory power of the older data, and in turn, of the independent variables. The RMSE indicators are 16.86 for Model A and 15.95 for

5 See Appendix 2 for complete results. 
Model D. Therefore, it is possible that the responsiveness of REIT to the economic conditions has shifted dramatically, and widely accepted paradigms may no longer apply.

\section{Conclusion}

My models suggest that REITs are unable to isolate their performance from temporary fluctuations of the economic environment completely. Specifically, there is strong evidence that suggests their returns might be vulnerable to market crashes since they follow the general patterns of the stock index. Even though they may not be subject to enthusiasm and disappointment during the periods of technological booms and crashes, REITs may undergo severe price reductions during mass selloffs caused by global economic recessions.

In contrast with some of the previous research, I found only little evidence that the total performance of the REIT industry is adversely affected by the dynamics of interest rates in the long run. Even though we cannot rule out the possibility REITs will experience temporary price reductions should the interest rates keep rising, their performance in the long horizon will most likely remain unaffected. This might be a reasonable explanation why REITs demonstrate more sensitivity to the short-term proxies of interest rates. Needless to say, this research was conducted from the perspective of a diversified investor. My choice of the FTSE Nareit Index did not allow me to fully inspect the effects of leverage on performance of individual REITs. Thus, one should keep in mind the limitations of this research, which might be inspirational for future research ideas.

To sum up, investors should never feel overly confident about the safety of their portfolios, because nothing keeps performing exceptionally well forever. Markets go through cycles that certainly will affect all publicly traded assets, so a proper hedging strategy or diversification should never be omitted. The risks, however, seem to be no higher than those of other high-yield assets.

\section{References}

Allen, M. T., Madura, J., Springer, T. M., 2000. REIT Characteristics and the Sensitivity of REIT Returns. The Journal of Real Estate Finance and Economics 21, 141-152. DOI: 10.1023/a:1007839809578.

Case, B., Yang, Y., Yildirim, Y., 2012. Dynamic correlations among asset classes: REIT and stock returns. The Journal of Real Estate Finance and Economics 44, 298-318. DOI: 10.2139/ssrn.1755592.

Chen, K., Tzang, D., 1988. Interest-rate sensitivity of real estate investment trusts. Journal of Real Estate Research 3, 13-22. 
Clayton, J., MacKinnon, G., 2001. The time-varying nature of the link between REIT, real estate and financial asset returns. Journal of Real Estate Portfolio Management 7, 43-54.

Cummins, L., Zochling, H., 2011. Distribution Payout Practices and the Collapse of A-Reits. Pacific Rim Property Research Journal 17, 598-613. DOI: 10.1080/14445921.2011.11104344.

Federal Reserve Bank of St. Louis (FED), 2018. Economic data and time series for research. St. Louis, USA. Available from: <https://research.stlouisfed.org/ useraccount/login/secure/>. [26 February 2018].

He, L. T., Webb, J. R., Myer, F. N., 2003. Interest rate sensitivities of REIT returns. International Real Estate Review 6, 1-21. DOI: 10.1023/ a: 1007771531534 .

Liang, Y., Prudential, W., Webb, J., 1995. Intertemporal changes in the riskiness of REITs. Journal of Real Estate Research 10, 427-443.

Nareit, 2018a. REIT market reports. Washington, USA. Available from: <https://www.reit.com/ data-research>. [26 July 2018].

Nareit, 2018b. List of FTSE Nareit Constituents. Washington, USA. Available from: <https://www.reit.com/sites/default/files/returns/FNUSIC2017.pdf> [25 February 2018].

Park, J. Y., Mullineaux, D. J., Chew, I. K., 1990. Are REITs inflation hedges? The Journal of Real Estate Finance and Economics 3, 91-103. DOI: 10.1007/ bf00153708.

Seiler, M., Webb, J., Neil Mye, F., 2001. Can private real estate portfolios be rebalanced/diversified using equity REIT shares? Journal of Real Estate Portfolio Management 7, 25-41.

Yahoo Finance, 2018. Index S\&P 500 data. Yahoo Finance Services. Available from: <https://finance.yahoo.com/quote/ \%5EGSPC/>. [26 February 2018]. 
Appendix 1: Constituent industries of the FTSE Nareit All REITs Index

\begin{tabular}{lrrr}
\hline Industry & Number of REITs & Market Cap. $\mathbf{( \$ M )}$ & $\begin{array}{l}\text { \% of Total } \\
\text { Market Cap. }\end{array}$ \\
\hline Equity REITs & 181 & $1,065,948$ & 94.02 \\
- Office & 24 & 105,076 & 9.27 \\
- Industrial & 12 & 74,046 & 6.53 \\
- Retail & 33 & 189,778 & 16.74 \\
- Residential & 22 & 146,539 & 12.93 \\
- Diversified & 18 & 63,703 & 5.62 \\
- Lodging/Resorts & 20 & 57,723 & 5.09 \\
- Self-Storage & 6 & 57,943 & 5.11 \\
- Health Care & 19 & 98,652 & 8.70 \\
- Other & 27 & 272,448 & 24.04 \\
Mortgage REITs & 41 & 67,750 & 5.98 \\
\hline Total & 222 & $1,133,698$ & 100.00 \\
\hline Source Nareit & $2018 b$ & &
\end{tabular}

Source: Nareit (2018b) + authorial computation.

Appendix 2: Regression models' diagnostics

\begin{tabular}{|c|c|c|c|c|c|c|}
\hline Model & $\begin{array}{l}\text { Dependent } \\
\text { variable }\end{array}$ & Period & $\begin{array}{l}\text { Wald test } \\
\text { market }\end{array}$ & $\begin{array}{l}\text { Wald test } \\
\text { interest rate }\end{array}$ & $\begin{array}{l}\text { Jarque- } \\
\text { Bera }\end{array}$ & RMSE \\
\hline A & REIT & 1972-1990 & $\begin{array}{r}3.88 \\
(0.00)\end{array}$ & $\begin{array}{c}-1.33 \\
(0.20)\end{array}$ & $\begin{array}{r}0.85 \\
(0.65)\end{array}$ & 16.86 \\
\hline B & EREIT & 1972-1990 & $\begin{array}{r}3.42 \\
(0.00)\end{array}$ & $\begin{array}{l}-1.31 \\
(0.21)\end{array}$ & $\begin{array}{r}0.83 \\
(0.66)\end{array}$ & 14.60 \\
\hline $\mathrm{C}$ & MREIT & 1972-1990 & $\begin{array}{r}2.94 \\
(0.01)\end{array}$ & $\begin{array}{l}-1.23 \\
(0.24)\end{array}$ & $\begin{array}{r}0.21 \\
(0.90)\end{array}$ & 27.42 \\
\hline $\mathrm{D}$ & REIT & 1972-2017 & $\begin{array}{r}4.62 \\
(0.00)\end{array}$ & $\begin{array}{l}-1,72 \\
(0.09)\end{array}$ & $\begin{array}{r}1.02 \\
(0.60)\end{array}$ & 15.95 \\
\hline $\mathrm{E}$ & EREIT & 1972-2017 & $\begin{array}{r}4.29 \\
(0.00)\end{array}$ & $\begin{array}{r}-1.83 \\
(0.07)\end{array}$ & $\begin{array}{r}0.60 \\
(0.74)\end{array}$ & 14.36 \\
\hline $\mathrm{F}$ & MREIT & 1972-2017 & $\begin{array}{r}2.53 \\
(0.01)\end{array}$ & $\begin{array}{r}-0.78 \\
(0.44)\end{array}$ & $\begin{array}{r}2.87 \\
(0.24)\end{array}$ & 26.14 \\
\hline
\end{tabular}

Source: Authorial computation.

Note: For Wald coefficient tests, t-statistics are presented in the first line. P-values in parentheses. RMSE = root mean square error. 
